\title{
Meaning of life as perceived by nurses at work in oncology palliative care: a phenomenological study*
}

\author{
O sentido da vida percebido pelos enfermeiros no trabalho em \\ cuidados paliativos oncológicos: estudo fenomenológico \\ El sentido de la vida percibido por los enfermeros en su trabajo con los \\ cuidados paliativos oncológicos: un estudio fenomenológico
}

How to cite this article:

Rocha RCNP, Pereira ER, Silva RMCRA, Medeiros AYBBV, Leão DCMR, Marins AMF. Meaning of life as perceived by nurses at work in oncology palliative care: a phenomenological study. Rev Esc Enferm USP. 2021;55:e03753. doi: https://doi.org/10.1590/S1980-220X2020014903753

Renata Carla Nencetti Pereira Rocha $^{1}$

\section{Eliane Ramos Pereira \\ Rose Mary Costa Rosa Andrade} Silva ${ }^{1}$

(D) Angelica Yolanda Bueno Bejarano Vale de Medeiros ${ }^{1}$

\section{iD Diva Cristina Morett Romano Leão ${ }^{1}$}

(iD) Aline Miranda da Fonseca Marins ${ }^{2}$

* Extracted from the thesis: "Percepção do sentido da vida pelo enfermeiro no trabalho em cuidados paliativos oncológicos", Escola de Enfermagem Aurora Afonso Costa Universidade Federal Fluminense, 2020

${ }_{1}$ Universidade Federal Fluminense, Escola de Enfermagem Aurora Afonso Costa Programa Acadêmico em Ciências do Cuidado na Saúde, Niterói, RJ, Brazil.

${ }^{2}$ Universidade Federal do Estado do Rio de Janeiro, Escola de Enfermagem Anna Nery, Departamento de Enfermagem Médico Cirúrgica, Rio de Janeiro, RJ, Brazil.

\begin{abstract}
Objective: To understand the meaning of life as perceived by nurses at work in oncology palliative care. Method: This is a qualitative study, with a phenomenological approach, based on the theoretical-philosophical framework by Viktor Emil Frankl. It was developed with nurses in a unit specialized in oncology palliative care located in the city of Rio de Janeiro and used phenomenological interviews. Data were processed using the phenomenological method by Amedeo Giorgi. Results: Thirty-four nurses participated in the study. The study conveys an existential message to nurses through selftranscendence. Through their work, they represent their own identity, which is directly impacted by the way they perceive freedom and responsibility in the face of actions taken. They build their reality and make work viable as a source of life. The care provided is no longer just a task to be qualified as a solidary, relational, existential, dynamic, and temporal issue. Conclusion: The experience in a scenario of life finitude allows these professionals to experience an authentic encounter with their self, the awakening of values giving meaning to their existence, and self-transcendence, deeply contributing to society through a more human, comprehensive, and quality assistance.
\end{abstract}

\section{DESCRIPTORS}

Neoplasms; Oncology Nursing; Palliative Care; Existentialism; Spirituality. 


\section{INTRODUCTION}

Meaning of life as one of the main existential questions of the human being has been investigated since the 20th century by traditional philosophical movements focused on the direction and ultimate purpose of life that could not be resolved by reason.

Based on the existential-phenomenological approach, the meaning of life emerges through the description of the specific structure of the phenomenon and is anchored in the lived experiences and in the meanings that the subject assigns to them ${ }^{(1)}$. This perceived meaning has an uninterrupted movement of significations as the individual experiences, perceives, remembers, thinks, judges, values, and desires something through the intentional experience resulting from the synchronicity between them and the experienced world ${ }^{(2)}$.

Supported by Viktor Frankl's existential-phenomenological theoretical framework, regarding the professional universe of nurses, when thinking about the meaning of life, there is a need to understand it mainly in its uniqueness and subjectivity, because it is linked to the experience in the context of palliative care. The existential meanings in the work of these professionals are reached by the roots of what is experienced, and the realization of the inner world takes place through the way it is felt rather than through its peculiar reference that is the act of taking care of life and of the other as a way of health production ${ }^{(3)}$.

An international study points out that the nurses' inclination to actions in this scenario of life finitude starts on what makes them move and act in the face of something they value as a means of profound pleasure, spiritual peace, and chances of self-realization ${ }^{(4)}$. It appears that these primary motivations, when well structured, lead these professionals to carry out their activities with greater technical autonomy, freedom of judgment, responsibility, and better ethical decision-making ${ }^{(5)}$.

Palliative care is a highly specialized care modality that aims to promote quality of life for patients and their families who face a disease that threatens life continuity ${ }^{(6)}$. This therapy supported by the Brazilian Cancer Prevention and Control Policy, established in Ordinance No. 874/2013, guarantees the integral, equitable, and universal right to health of these citizens who need to maintain the quality of life and control symptoms until the moment life ends.

In their work, professionals working in palliative care, when confronted with patients' existential issues due to their inexorable fate, have emotional fluctuations elicited, as well as expressive reflections on their own lives and on the importance of the care provided to the patient ${ }^{(7)}$. Nurses' work shall not be configured as a single task or activity, but as a form of expression, of relationship with oneself, with others, and with the world to which they connect and, therefore, as an opening for the meaning of life ${ }^{(8)}$.

National and international literature is scarce with regard to the valuation of nurses' existential issues, and for the most part, focuses on patients facing barriers in their work practices. The study was motivated by the identification of the need to study the subjectivity permeating the meaning of life for these professionals who work in oncology palliative care, with the premise that, through this knowledge, they are placed in their entirety faced with their role, uniting them to the patient in a consistent and comprehensive manner.

It is thought that the study is relevant as it opens a strategic window of reflection for nurses concerning their conceptions, values, and experiences about the meaning of their existence, with emphasis on their work activity. Thus, through the construction of knowledge, they mean a purpose to their lives in the context in which they are inserted and, in view of that, they develop strategies that encourage them to enable personal and professional self-development, and a more dynamic, authentic health production, with ethical and moral commitment to patients and their families.

It is important to inform that the present study is in agreement with the Health Research Agenda ${ }^{(9)}$ released by the Ministry of Health, as it is aimed at meeting the nurses' demands of the bio-psycho-social and spiritual dimensions which directly interfere in existential issues to which they are exposed and that lead to a number of implications for health, safety, and results in the work itself.

Therefore, the theme is consolidated as a research priority because it works as an instrument that induces study initiatives and resource allocation that impact on the strengthening of health services with multiple benefits for those who provide care and those who are receiving such care.

It is noteworthy that, through actions to expand service networks aimed at improving the quality of care for health professionals, as well as interventions that can establish the existence of nurses in the "world" of palliative care work, it is possible to reduce the care gap that may interfere with the best care provision to the patient.

Therefore, considering the above, the following guiding question was elaborated: What is the meaning of life as perceived by nurses at work in oncology palliative care? To answer the study question, the objective of the study consisted of understanding the meaning of life as perceived by nurses at work in oncology palliative care.

\section{METHOD}

\section{TYPE OF STUDY}

This is a qualitative study, with a phenomenological approach, based on the theoretical-philosophical framework by Viktor Emil Frankl who, taken by the phenomenological method, states that the meaning of life is guided by the search for meanings of the human being existence and that this search corresponds to their main motivating force to maintain their existence ${ }^{(10)}$.

\section{LOCAL}

The field of study chosen was the palliative care hospital unit of a Reference Center for High Complexity Assistance in Oncology of the Ministry of Health, located in the city of Rio de Janeiro. 


\section{Population}

The study participants were 34 nurses who worked in a hospital unit of oncology palliative care and performed their activities in the assistance and/or administrative modality.

The inclusion criterion was to have more than one year of experience in this type of assistance, as it is the minimum period required for the professional to be engaged with the work at the institution. Nurses who were on a sick leave, maternity leave, or on vacation during the interview period were excluded. It should be noted that the number of participants in this study was limited when data saturation was detected and, consequently, the objective of the proposed study was achieved.

\section{Data collection}

Data collection was performed by the researcher in charge of the study, a doctoral student in the Academic Graduate Program in Health Care Sciences and nurse at the hospital unit which was the study field.

Data were collected between March and June 2019 using the phenomenological interview technique. As this interview is a technique focused on subjective demand, it reinforces some peculiar characteristics such as: avoidance of prejudice, value judgment, categorizations, as well as avoidance of anticipated interpretations of the reality studied.

Therefore, the conduction of the interview by the previously trained researcher was based on the setting, empathy, and intersubjectivity ${ }^{(11)}$. These measures allowed the commitment between the researcher and the study participants, providing an openness to listening between them that went beyond appearances, so that the true expression of meanings could be achieved in the real moment of the interview.

For the phenomenological interview, a script containing a question of approach was used: - "How is your experience working on oncology palliative care?"; and a guiding question: - "Tell me, what meaning of your life is extracted from the work in oncology palliative care?" The information was recorded and transcribed in the days following the interviews. Complementing the characterization of the study participants, a sociodemographic and professional form was applied, clarifying the understanding of the profile studied.

\section{Data ANALYSIS AND TREATMENT}

To understand the experiences reported in the data collected from the interviews, the phenomenological investigation method proposed by Amedeo Giorgi was used. In this method of analysis, a descriptive approach to the phenomenon is proposed, based on the essences or structures of the experiences, to bring the participants' experiences regarding the meaning and signification they assign ${ }^{(8)}$ to the spoken world. This method is operationalized in four steps: 1 - Reading of the experience description, to reach the general meaning of the whole. 2 - Rereading of the text and definition of significant units (reducing the text into smaller parts with important meanings that are concentrated in this "unit"). 3 - Transformation of each unit of meaning into psychological language (after discriminating the significant units, the common sense language is transformed into psychological-scientific language, revealing the psychological meaning experienced by the participants). 4 - Synthesis of the significant units in a general structure of the studied phenomena, thus composing the subject's experience through a general descriptive structure ${ }^{(12)}$.

In this step, the meaningful interview fragments that answered the study guiding question were identified and grouped by similarity, categorized, discussed, and interpreted based on perspective of Viktor Frankl's theoretical-philosophical framework.

\section{ETHICAL ASPECTS}

In the study, ethical care prevailed, in compliance with the Resolution no. 466/2012 of the National Health Council, which regulates the standards for research involving human beings.

The study was initiated after approval by the Ethics and Research Committee under reports no. 2.985.607/2018 and 3.063.980/2018, from Universidade Federal Fluminense and Instituto Nacional do Câncer, respectively. The subjects signed the Free and Informed Consent Form to participate in the study. To ensure the confidentiality of the information and the anonymity of the nurses participating in the study, the statements were coded by the capital letter "E" plus the Arabic number corresponding to the ascending chronological order of the interviews.

\section{RESULTS}

It was found that, of the 34 nurses interviewed, 31 (91.17\%) were women, between 29 and 69 years old. Most of them, 33 (97.05\%), reported being connected to some type of religion. Regarding the performance of their roles, 29 (85.29\%) reported developing their activities in direct care. Concerning the work schedule, 14 (41.17\%) informed they worked on duty shifts and $5(14.70 \%)$ of them specifically at night. As for the years of work as a nurse, 20 (58.82\%) stated that they had more than five years in the area and only 12 (35.29) had worked for less than 5 years at the institution. All of them, 34 (100\%), reported having a specialization or residency in oncology.

Following the nurses' statements analysis, based on the four stages of Amedeo Giorgi's method, four thematic categories emerged, namely: work as its own meaning; freedom and responsibility conditioning the unveiling of the meaning of life; the sense of alterity in care and interrelationships; life self-transcendence through the work carried out in oncology palliative care.

\section{WORK AS ITS OWN MEANING}

For nurses, the nature of the work itself is presented as a critical condition of their own existence. Through work, nurses represent their own identity, build their reality, and make their work viable as a source of life.

It is an encounter with your identity. Do you know why? Because when you see the patient in his most fragile moment of suffering and such, you end up identifying (...), exercising your most bu- 
man side, your most sensitive side and you recognize yourself. You identify your limitations, you identify your potentialities, you identify your qualities, your defects (E17).

I think that what we choose to do with our life is part of our identity. It is what you are! It is an encounter with yourself (E13).

Working here I have a financial reward, through this I can provide quality education, food and health insurance for my girls (...). But I also teach them from everything we live here, to respect the differences of others, I teach them to respect all differences (social, cultural, disease) (E12).

It gives me strength, it means me, it builds me, it gives me meaning (....). I am here because I was born for this here (E5).

\section{FREEDOM AND RESPONSIBILITY CONDITIONING THE UNVEILING OF THE MEANING OF LIFE}

The life that is meaningful because of work is made possible through decisive connections between nurses' work practice and freedom and responsibility. In this study, freedom of choice for the work performed is essentially related to the nurses "being" responsible for their actions and postures adopted.

It is a path that I chose to follow. There are choices, and I did make that choice (...). I try to improve myself to do better and better. For me to offer the best, I need to technically improve myself because suffering does not wait, and if I am not sure of what I am doing for the other, I can miss important moments of quality, of relief, of comfort. It is doing the best that can be done. It is to have changes in your world, in your way, in your existence. It means empathizing with the suffering of others, helping in the process, but understanding that the problem, the suffering, belongs to the other and not to us (E3).

When I was called for the position, I wanted to come to Inca [National Cancer Institute] IV. I knew a doctor who worked here and he said: "The warehouse? I said: yes, it is there that I want to work (E9).

When I stop to reflect on my life, my family, my community, my work, I feel very much like this: I am part of and responsible for the environment I live in. So I have to have pity, charisma and to offer the best in me to patients (E29).

\section{THE SENSE OF ALTERITY IN CARE AND INTERRELATIONSHIPS}

Care is the existential reason for the work of nurses and in this study it is felt through the nurse/patient/family interrelation as alterity.

It is giving what I set out to do, which is the best of me in caring for others, with people, with relationships (E22).

Work brings it to me, it goes beyond my profession. It is something that I am doing to improve the quality of life of the other being, of a patient from a suffering family. It is to be useful because I belped someone, to have been part of someone's life (E34).

It is trying to take the pain away from the patient. It is trying to mitigate the patient's suffering in the best way possible. Even if it is by trying to change the prescription, attending an emer- gency. It is not waiting for the colleague to do it. It is going to run there to do it, because I think that each minute reduces that patient's distress (E15).

It is to give peace where it is difficult to have peace, right? It is to give peace to the patient and somehow bring a meaning of life to him even in the face of suffering (E33).

\section{LIFE SELF-TRANSCENDENCE THROUGH THE WORK CARRIED OUT IN ONCOLOGY PALLIATIVE CARE}

Finding the whole meaning of life, structured by the spiritual dimension, awakens the nurses' life self-transcendence and is manifested by the discoveries of values that were hidden before the experience in Oncology Palliative Care.

Spirituality gives me a basis for me to be able to understand a little about the things we experience at work, about the various questions for which I cannot find the answer here (E30).

You learn to value simple actions that for many go unnoticed, such as eating with your own hands and mouth, breatbing alone and effortlessly, walking, among others. It is a daily learning that you look to the side and see that you are very happy, you know? (E1).

I value life more. I am more grateful, a less complaining person. I give more value to my family and to be with the people I like. Material values are different (E27).

I believe it is a transformation as a person, as science, as a professional. It is the true butterfly in constant transformation (E12).

It is an improvement in life experience, spirituality, emotional development and family development (E13).

It is to be a positive link. It is believing when people have already given up believing. It is knowing that even when working with a lot of pain, suffering, anguish, even in that difficult area there, there is always something that we are able to give and at the same time learn something from there (E32).

\section{DISCUSSION}

The phenomenon of perceiving meanings for life through work constitutes, for nurses, a multidimensional and dynamic construct that encompasses a set of variables according to their experiences, existence, and initiatives in oncology palliative care.

This study allowed the comprehension that work emerges as an act that makes nurses become intertwined in the ways they exist and are in the world and that it leads them back to the encounter with their totalities ${ }^{(2)}$. The meaning assigned to work is given as the individual is able to recognize themselves through the way they give meaning to their relationship "at", "of" and "with" their own work ${ }^{(7)}$. There is no doubt that the human being is thrown into the world of work to meet their needs, especially of a socioeconomic nature, as a minimum guarantee of survival ${ }^{(13)}$.

However, previous studies point out that the financial factor is considered complementary and not essential for work to make sense in their lives. For nurses, remuneration works as an extrinsic factor for motivation at work, since most of them classify it as inadequate, unfair, and inconsistent with 
expectations and needs regarding their role with patients and health institutions ${ }^{(14)}$. It is evident that the meaning is representative of a more personal dimension and it is not just a question of financial independence, but of personal values imposed by each person.

Regarding the field of oncology palliative care, which is aimed at assisting critically ill patients with the potential for imminent death, the work, by evoking the reflection of these professionals on their lives and the perception of the real value of their existence, dampens the destructive effects on their health, such as symptoms of burnout syndrome and existential emptiness $^{(15)}$.

The work is aligned with their being and represents their expression of "man" in the world. Corroborating with a study developed abroad, it is represented as the identity itself; it appears as the character of something unique to their existence and that, in view of this, allows the anticipation of consequences of their actions ${ }^{(16)}$. All of this because they understand the goal and purpose of their task both in their own work and in their lives.

It is not the work that offers man the possibility of reaching fullness. This state of completeness is achieved when the inner world achievements are undertaken through the achievements in the world with the other, as in the case of nurses working in oncology palliative care ${ }^{(17)}$. Work represents the field of something of unique nature, receiving its true meaning and value when the individual has the moral conscience to dedicate themself to a task or to someone in a way that is not only for their exclusive benefit ${ }^{(18)}$. Thus, the work itself is not enough to make man part of a whole and irreplaceable; what it does is simply to give the professional the ability to become this ${ }^{(18-19)}$.

This relationship of nurses with others (patients/family members) and with themselves in the world of palliative care is impacted by the way they perceive their freedom and responsibility. Man is a being conceived as an agent who decides and responds responsibly to the freedom that the world gives them $^{(20)}$. Freedom appears as the field of possibility of choosing for nurses who have decided to work with the condition of human finitude. In addition, this freedom does not mean being free from something, but rather being able to make decisions through the core of your being, thus configuring your being in the world ${ }^{(2)}$. This freedom of choice is essentially about being responsible, as these professionals are, for their actions and postures adopted. That is, for the results of the work carried out to be clear and meaningful, it is important that they have a sense of accomplishment of their tasks regarding ethical and moral behavior, personal, social, and spiritual valuation.

Nurses'work main task and existential reason is care; and, in this study, it appears as a state or condition in which they perceive their existence through the contact with the "other" (patients/families) for what they are not. Importantly, when there is an intentionality in the care, from the nurses to the patients, in a true expression of alterity, the term "care" itself is no longer just a task and is qualified as a solidary, relational, existential, dynamic, and temporal condition ${ }^{(5)}$.
In the nurse/patient relation, the only functional and impersonal relationship is surpassed, reaching the personal relationship in which a "you to you" relation with the other is established, a world of "us"(21). This refers to the understanding that, at the same time that nurses take care of the other, they are taking care of themselves as it is their closest possibility to being. When they open themselves for the care of others, they assume a deliberate nature for what matters, or rather, what is important in itself, involving ethics, morality, and affection.

The meaning of life at work lies in giving oneself and reflecting on one's way of being, especially when assuming care as a moral imperative value arising from a meditative awareness that singularly rescues its own value as a human ${ }^{(18)}$. For Frankl, "giving yourself" to the other as absolute alterity is the inter-existential way in which the "being" of a person "in" another is recognized as such, going further ${ }^{(20)}$. Therefore, the meanings assigned to the work do not stem from an altruism that exceeds the being, but thought in the plurality of the human relationship, stem from an intersubjective knot, in a mundane context.

In contrast, some factors permeating nurses' professional practice, such as the devaluation of the workforce, work overload, "carelessness" of the institution regarding their subjective needs, exhaustive working hours, as well as the very temporality of their existence in a place permeated by patients' death, pain, anguish, and suffering, represent a threat to their emotional health, and interfere with the potential for intrinsic motivation that implies quality of the care provided to the patient, in the long term ${ }^{(22)}$.

As a balance point, in international settings, there are health institutions adopting educational interventions in the work dynamics, such as training programs with personal values, to supply these professionals with existential self-awareness, self-efficacy, personal and professional selfdevelopment, considering the broad benefits regarding the production of their tasks for society ${ }^{(23-24)}$.

Spirituality is identified as the dimension that enables nurses to face adversities found at work. This dimension is significant for these professionals since it presents itself as a catalyst and decoder of the existential phenomena experienced $^{(25)}$. The spiritual dimension is the founding essence of the human species and allows man to manifest their freedom, responsibility, ability to value; to position themself; to decide; and to question themself about the meaning of their existence $^{(20)}$. This dimension is an abyssal, primary, and genuinely human instance that mobilizes these professionals to materialize their existences and check the possibility of selftranscendence through the full encounter with themselves.

However, the uniqueness of each human being shall be considered; that is, the fact that each person is unrepeatable, paradoxical, and open to infinite possibilities and values that enable them to affirm their motivating will to perform, generating meaning to their existence ${ }^{(10,19)}$. These values are principles that influence human beings' behaviors, both in their conduct and in their way of thinking ${ }^{(5)}$. They represent the human beings' convictions of what they believe is good, 
correct, or desirable, and determine the way they behave and interact.

According to Frankl's phenomenological approach, these values are mentioned as what is considered significant, motivating, and that crystallizes the meaning of life for each individual ${ }^{(10,19)}$. For instance, in this study, the values were veiled and underlying the nurses' experiential universe, and the essence of such values was related to the valorization of life, health, personal transformation, re-encounter as a professional, experience, and learning.

Nurses "crossed" by the experience of human finitude, when they leave themselves and go to meet the other (patients/family members) through their work, change internally, and this experience facilitates the emergence of a new posture in relation to life ${ }^{(25)}$. This change, in its turn, is manifested by the essential quality of human existence, self-transcendence.

Self-transcendence evokes the sense of fullness of life and takes place through the path of temporal experiences and of the historicity of each one ${ }^{(26)}$. On the existentialphenomenological approach, self-transcendence does not emerge from conceptual and predetermined paths, but from the authentic understanding of the individuals in their existence that arises through their condition of being in the world, in their relationship with themselves and with others, and through the construction of their history in time ${ }^{(2)}$.

The theoretical-philosophical framework studied understands that existence is not an end in itself, limited to a constant search for pleasure, power and prestige, or even bound to biopsychosocial conditions ${ }^{(18)}$. On the contrary, it overflows and opens up to the world when man realizes that he is always primarily oriented towards something other than himself, through dedication to a task, in the service of a cause, a work or love for another person ${ }^{(10)}$. In other words, as man fills out a meaning out there, it is in the world that they will feel fulfilled.

Through the movement of getting out of themselves, nurses have the possibility of contemplating the beauty of life and the existential encounter through the dedication and donation to the other, which is made possible through the work performed ${ }^{(27)}$. Self-transcendence is identified as corresponding to the deepest path that penetrates the truly human space (spiritual dimension) and, in view of this, allows the genuine full realization of the meaning of life that goes beyond its own limits.

It is expected that this study leads to a reflection on nurses' practice focused on social and management issues, and no longer as a routine and repetitive effort of their duties. It is believed that the best work performance and composition of care integrality shine when the individual/personal essence is known and valued, thus shortening the distance between the purposes of both of them in the work environment.

The participation of health service managers on structural and organizational issues that directly interfere with the practice and existential meaning of these professionals in the work environment is placed in a prominent position. It is useful for managers to have their responsibilities and behaviors aligned regarding their role towards nurses, so that, if necessary, they develop and adopt measures that meet the needs of this specific population, an attitude that is essential to meet the organization's goals.

The study gathers subsidies for nurses to reflect on the guiding principle of their existence at work and to optimize their professional practice in a dynamic of potentialities, freedom, and responsibility with dignified and valuable attitudes to patients.

Concerning the limitations of the study, its performance in a single scenario of oncology palliative care in the hospital context makes it impossible to generalize the data for the entire national territory.

\section{CONCLUSION}

The nature of this study allowed the understanding that the work in palliative care conveys to nurses an existential message through self-transcendence. Conducted based on the phenomenological-existential perspective, it was revealed that the meaning of these professionals' lives is linked to the character of uniqueness and unrepeatability of their existence through work.

The experience in the scenario of finitude of life allows nurses to have an authentic encounter with their self and the possibility of anchoring life with greater motivation and assertiveness. Hidden behind the values is the master key that motivates these professionals to give meaning to their work and to self-transcend with potential benefits for a more humane, comprehensive, and good quality assistance.

Nursing as a science that provides care under the biological, psychological, social, and spiritual dimensions of another being also needs to have the individual essence recognized and valued, both by itself and by its managers, to shorten the distance between the purposes of both of them in the work environment.

Although the theme of the meaning of life is a subject being disseminated in the health area, in the nursing area it is still incipient and has to have its investigations expanded with the prerogative of these professionals supporting the ability of self-transcendence and awakening meanings for the reasons for being in the world with great contributions to society.

\section{RESUMO}

Objetivo: Compreender o sentido da vida percebido pelos enfermeiros no trabalho em cuidados paliativos oncológicos. Método: Estudo de natureza qualitativa, com abordagem fenomenológica, fundamentado no referencial teórico-filosófico de Viktor Emil Frankl. Desenvolveu-se com enfermeiros em uma unidade especializada em cuidados paliativos oncológicos localizada no município do Rio de Janeiro por meio de entrevista fenomenológica. Os dados foram tratados pelo método fenomenológico de Amedeo Giorgi. Resultados: Participaram 34 enfermeiros. O trabalho veicula para os enfermeiros uma mensagem existencial por meio da autotranscendência. Pelo trabalho, representam a própria identidade que é diretamente impactada pela forma como percebem a liberdade e responsabilidade perante as ações assumidas. Constroem a sua realidade e o viabilizam como fonte de vida. $\mathrm{O}$ cuidado prestado deixa de ser apenas uma tarefa para ser qualificado como uma condição solidária, relacional, existencial, dinâmica e temporal. Conclusão: A experiência no cenário 
da finitude da vida possibilita a estes profissionais o encontro autêntico com seu eu, o despertar de valores que dão sentido a seu existir e à autotranscendência, contribuindo profundamente à sociedade por meio de uma assistência mais humana, integral e de qualidade.

\section{DESCRITORES}

Neoplasias; Enfermagem Oncológica; Cuidados Paliativos; Existencialismo; Espiritualidade.

\section{RESUMEN}

Objetivo: Comprender el sentido de la vida percibido por los enfermeros en su trabajo con los cuidados paliativos oncológicos. Método: Estudio de carácter cualitativo, con abordaje fenomenológico, fundamentado en el referencial teórico-filosófico de Viktor Emil Frankl. Se desarrolló con enfermeros de una unidad especializada en cuidados paliativos oncológicos ubicada en el municipio de Río de Janeiro mediante entrevistas fenomenológicas. Los datos fueron tratados con el método fenomenológico de Amedeo Giorgi. Resultados: Han participado 34 enfermeros. Para ellos, el trabajo transmite un mensaje existencial a través de la autotrascendencia. Con su trabajo, representan su propia identidad, que se ve directamente impactada por la forma en la que perciben la libertad y la responsabilidad hacia las acciones practicadas. Construyen su realidad y la convierten en una fuente de vida viable. El cuidado que se presta deja de ser una mera tarea para calificarse como una condición solidaria, relacional, existencial, dinámica y temporal. Conclusión: La experiencia en el escenario de la finitud de la vida permite a estos profesionales el auténtico encuentro con sí mismos, el despertar de los valores que dan sentido a su existencia y la autotrascendencia, contribuyendo profundamente hacia la sociedad a través de una asistencia más humana, integral y de calidad.

\section{DESCRIPTORES}

Neoplasias; Enfermería Oncológica; Cuidados Paliativos; Existencialismo; Espiritualidad.

\section{REFERENCES}

1. Roehe MV. Psicologia e filosofia na abordagem fenomenológico-existencial: um estudo sobre Frankl e Heidegger. Rev Abordagem Gestalt. 2019;25(3):323-30. doi: http://dx.doi.org/10.18065/RAG.2019v25n3.11

2. Merleau-Ponty M. Fenomenologia da percepção. $4^{a}$ ed. São Paulo: Martins Fontes; 2015.

3. Lee SA. Concept analysis of 'meaning in work' and its implications for nursing. J Adv Nurs. 2015;71(10):2258-67. doi: 10.1111/jan.12695

4. Pérez-Vega ME, Cibanal-Juan L. Personal narratives of nurses who care for patients at the end of life. Int J Palliat Nurs. 2020;26(1):14-20. doi: 10.12968/ijpn.2020.26.1.14

5. Rocha RCNP, Pereira ER, Silva RMCRA. A dimensão espiritual e sentido da vida na prática do cuidado de enfermagem: enfoque fenomenológico. Rev Min Enferm. 2018;22:e-1151. doi: http://www.dx.doi.org/10.5935/1415-2762.20180082

6. Gomes ANZ, Othero MB. Palliative care. Estud Av. 2016;30(88):155-66. doi: http://dx.doi.org/10.1590/s0103-40142016.30880011

7. Moreno-Milan B, Cano-Vindel A, Lopez-Dóriga P, Medrano LA, Breitbart W. Meaning of work and personal protective factors among palliative care professionals. Palliat Support Care. 2019;17(4):381-7. doi: 10.1017/S147895151800113X

8. Parola V, Coelho A, Sandgren, A, Fernandes O, Apóstolo J. Caring in palliative care: a phenomenological study of nurses' lived experiences. J Hosp Palliat Nurs. 2018;20(2):180-6. doi: 10.1097/NJH.0000000000000428

9. Brasil. Ministério da Saúde. Agenda Nacional de Prioridades de Pesquisa em Saúde. [Internet]. Brasília; 2018 [citado 2020 mar. 16]. Disponível em: http://bvsms.saude.gov.br/bvs/publicacoes/agenda_prioridades_pesquisa_ms.pdf

10. FrankI VE. Em busca de sentido: um psicólogo no campo de concentração. Petrópolis: Vozes; 2017.

11. Alves FAM, França LRF, Melo AK. Entre o nascer e o morrer: cuidados paliativos na experiência dos profissionais de saúde. Rev Bras Promoção Saúde. 2018;31(1):1-10. doi: 10.5020/18061230.2018.6712

12. Silva RV, Oliveira WF. The phenomenological method in health researches in Brazil: an analysis of scientific production. Trab Educ Saúde. 2018;16(3):1421-41. doi: https://doi.org/10.1590/1981-7746-sol00162

13. Neves DR, Nascimento RP, Felix Junior MS, Silva FA, Andrade ROB. Sentido e significado do trabalho: uma análise dos artigos publicados em periódicos associados à Scientific Periodicals Electronic Library. Cad EBAPE.BR. 2018;16(2):318-30. doi: https://doi.org/10.1590/1679395159388

14. Duarte JMG, Simões ALA. Significados do trabalho para profissionais de enfermagem de um hospital de ensino. Rev Enferm UERJ. 2015;23(3):388-94. doi: https://doi.org/10.12957/reuerj.2015.6756

15. Ong KK, Ting KC, Chow Y. The trajectory of experience of critical care nurses in providing end-of-life care: a qualitative descriptive study. J Clin Nurs. 2018;27(1-2):257-68. doi: https://doi.org/10.1111/jocn.13882

16. Malloy DC, Fahey-McCarthy E, Murakami M, Lee Y, Choi E, Hirose E, et al. Finding meaning in the work of nursing: an international study. Online J Issues Nurs. 2015;20(3):7. doi: https://doi.org/ 10.3912/OJIN.Vol20No03PPT02

17. Gómez-Salgado J, Navarro-Abal Y, López-López MJ, Romero-Martín M, Climent-Rodríguez JA. Engagement, passion and meaning of work as modulating variables in nursing: a theoretical analysis. Int J Environ Res Public Health. 2019;16(1):108. doi: 10.3390/ijerph16010108

18. FrankI VE. Psicoterapia e o sentido da vida. $6^{\mathrm{a}}$ ed. São Paulo: Quadrante; 2019.

19. Frankl VE. A vontade de sentido: fundamentos e aplicações da logoterapia. São Paulo: Paulus; 2017.

20. FrankI VE. Logoterapia e análise existencial: texto de seis décadas. Rio de Janeiro: Forense Universitária; 2017.

21. Baggio MA, Erdmann AL. A circularidade dos processos de cuidar e ser cuidado na conformação do cuidado "do Nós". Rev Enf Ref. 2015; ser IV(7):11-20. doi: http://dx.doi.org/10.12707/RIV15012

22. Portero de la Cruz S, Abellán MV. Professional burnout, stress and job satisfaction of nursing staff at a university hospital. Rev Latino Am Enfermagem. 2015;23(3):543-52. doi: 10.1590/0104-1169.0284.2586 
23. Frey R, Balmer D, Boyd ML, Robinson JA. Palliative care nurse specialists' reflections on a palliative care educational intervention in longterm care: an inductive content analysis. BMC Palliat Care. 2019;18(1). doi: 10.1186/s12904-019-0488-4

24. Henoch I, Strang S, Browal M, Danielson E, Melin-Johansson C. Development of an existential support training program for healthcare professionals. Palliat Support Care. 2015; 13(6):1701-9. doi: https://doi.org/10.1017/S1478951515000632

25. Medeiros AYBBV, Rocha RCNP, Pereira ER, Silva RMCRAS, Gil Moncayo FL. El sentido de la vida como recurso espiritual para el cuidado en oncología. Rev Cuba Enferm [Internet]. 2018 [citado 2019 nov. 19];34(4). Disponible en: http://www.revenfermeria.sld.cu/index.php/ enf/article/view/2243

26. Guerrero-Castañeda RF, Prado ML, Menezes TMO, Galindo-Soto JA, Ojeda-Vargas MG. Life experiences that favor the plenitude and transcendence of the elderly being: a phenomenological-hermeneutical study. Rev Esc Enferm USP. 2019;53:e03476. doi: https://doi. org/10.1590/s1980-220x2018029303476

27. Hwang HL, Tu CT, Chan HS. Self-transcendence, caring and their associations with well-being. J Adv Nurs. 2019;75(7):1473-83. doi: 10.1111/jan.13937 